\title{
RETORNOS DE CAPITU
}

\author{
Marilene Weinhardt*
}

$\square$ esde os anos 80 do século XX, a ficção histórica vem demonstrando extraordinária vitalidade, em número de títulos e não raro no alcance da realização. Por vezes, o entrelaçamento da ficção com a história toma um viés particular: ficcionaliza-se a própria história literária, focalizando-se épocas e/ou personagens da vida literária. Neste retorno à tradição, quer para confirmála, quer para questioná-la, Machado de Assis, como seria de esperar, ocupa posição de destaque.

Vislumbra-se a presença de Machado na cena contemporânea em momentos diferentes e de formas variadas. Os romances que, sem buscar diálogo mais intenso com a história literária, situam a ação na segunda metade do século XIX, no espaço do Rio de Janeiro, assinalam, de alguma forma, a presença do cidadão Joaquim Maria Machado de Assis. Os recursos retóricos, particularmente o discurso irônico e o modo específico de uso de metáforas que nivelam o abstrato e o concreto, ecoam nas mais diversas opções narrativas. A recorrência ao discurso memorialístico que vela e revela assume, de modo explícito ou não, a natureza de tributário do modelo inconfundível.

A despeito dessa pluralidade, é no entrecruzamento de duas linhas - a ficcionalização da história literária e o diálogo com o passado - que se inscreve a presente abordagem, com recortes ainda mais estreitos: a retomada de Dom

* Universidade Federal do Paraná. 
Casmurro em textos ficcionais. São três os romances comentados: Enquanto isso em Dom Casmurro (1993), de José Endoença Martins; Capitu: memórias póstumas (1998), de Domício Proença Filho; e Amor de Capitu (1999), de Fernando Sabino. Note-se o recurso da migração de personagens ficcionais de um texto para outro e a freqüentação de um mesmo título. Na produção crítica, não faltam estudiosos que apontem a força da figuração de Capitu, esbanjando-se adjetivos para qualificá-la. Quando se transita da influência para o que vem sendo chamado de crítica-ficção, ainda que sem levantamento exaustivo, parece ser possível afirmar, sem muito risco de erro, que é o caso mais significativo, numericamente, na ficção brasileira, seja tendo em vista o título Dom Casmurro, seja tendo em vista uma personagem em particular. É o caso de lembrar ainda de exercícios mais breves. Dalton Trevisan, em texto indeciso entre o conto e a crítica impressionista - "Capitu sem enigma"1 - afirma ser impróprio e empobrecedor colocar-se em dúvida a infidelidade de Capitu. Antonio Carlos Secchin anexa a texto crítico exercício de criação intitulado "Carta ao Seixas", ${ }^{2}$ evidentemente o marido de Aurélia, assinada por certo Bento de Assis, que relata a constatação de que seu suposto filho com a esposa Lina carrega os gens de um "tal Machado", presente na "seção literária das gazetas" antigas.

A propósito, vale observar que as figuras femininas alencarianas também vêm atraindo os ficcionistas. Aurélia é evocada com alguma freqüência no romance de Proença Filho e uma Lúcia que se desdobra em vários duplos estudante/meretriz, branca/negra, irmã gêmea - divide a cena com o mestre Alencar e seu orientando, professor-narrador no romance Lúcia, ${ }^{3}$ de Gustavo Bernardo. Eventualmente, as personagens ficcionais que emprestam o nome de personagens empíricas que foram escritores são caracterizadas como professores no presente da narração, destino que caberá também a Machado, como se verá a seguir.

Ainda no item professores, agora francamente empíricos, um levantamento de obras de ficção recentes assinadas por professores de literatura certamente contaria com vários títulos.

O livro do catarinense e professor na Universidade de Blumenau José Endoença Martins faz com que Capitu, sentindo-se chateada e oprimida na voz

1 Gazeta do Povo, Curitiba, 23 maio 1993. Caderno G, p. 2. Dinorá. Rio de Janeiro: Record, 1994. p. 29-36.

2 In: Machado de Assis. Uma revisão. Rio de Janeiro: In-Fólio, 1998. p. 131-134.

3 Rio de Janeiro: Relume-Dumará, 1999. 
masculina e passadista, evada-se do espaço-tempo do original. Em Enquanto isso em Dom Casmurro, ${ }^{4}$ Capitu foge do destino que lhe deu Machado de Assis e casualmente cai em Blumenau, em plena Oktoberfest. É negra e veste-se à moda de Sula Miranda. Define-se como uma outsider anônima. Recorre à cocaína com desenvoltura e não recusa nenhuma forma de experiência sexual, inclusive com o velho professor de literatura da universidade, personagem denominada Machado de Assis, que sofre de epilepsia e está escrevendo um romance. Mas a preferência de Capitu é pelo relacionamento com a empregada branca, de origem alemã, que atende pelo sugestivo nome Conike.

São chamados à cena, sem qualquer modalidade de hierarquização, fatos culturais e personagens das mais variadas extrações. Madonna, Zezé Mota, Paul Simon e Garfunkel dividem espaço com evocações e citações de John Barth e Fernando Pessoa. Sílvio Santos ombreia com Woody Allen. Capitu interage com Michael Douglas e Glenn Close. Conceitos de Derrida e o nariz de Bergerac são evocados na mesma sensação. Filmes como Ligações perigosas, Atração fatal e A rosa púrpura do Cairo fazem parte do mesmo background da canção Caminhoneiro do amor. Transcrições das revistas Interview e Isto é aparecem lado a lado, cumprindo funções equivalentes na abertura de capítulos. Não há barreiras nem ontológicas, nem temporais e nem geográficas entre Magic Jonhson e Sherlock Holmes. Nas ruas da cidade convivem o pop e o sertanejo cowboy, pivetes e agro-girls, como no campus universitário dividem espaço o mundo acadêmico e o comércio de sacoleiros. Expressões das mais chulas podem aparecer na mesma página em que se expõe uma teoria do simbólico, se apresenta uma discussão sobre o pós-moderno ou se questiona o processo de criação na linguagem. Desejar é poder.

Ou melhor, nomear é poder. O universo em que circula Capitu é o da linguagem, princípio explicitado na narrativa até a exaustão. Daí, ao constatar o modo de vida à sua volta, ela conseguir imediatamente os meios de se integrar nesse espaço, sem pruridos realistas da parte da narrativa. Quando a situação é desfavorável ou de risco, ela volta para Dom Casmurro, momento em que aproveita para discutir com o marido Bento Santiago e, claro, sempre discordar dele e criticá-lo.

A despeito desse volume de elementos, a narrativa é relativamente curta, num total de 126 páginas, doze capítulos, que obedecem predominantemente a mesma estrutura, quase sempre iniciados com citação dos periódicos já indicados. O último capítulo rompe com o tom irreverente predominante na

4 Florianópolis: Paralelo 27, 1993. 
narrativa, optando sem subterfúgios por um discurso de dignificação de minorias, produzindo-se uma espécie de apêndice dissonante. Mulheres negras, pobres ou nem tanto, são santificadas. O refúgio em Dom Casmurro, que ocorre por quatro vezes, tem numeração própria, em algarismos romanos (os capítulos tem numeração arábica). O narrador-autor, que não disfarça o estatuto de professor de Literatura Anglo-americana na linguagem e no repertório cultural, comparece explicitamente algumas vezes, quase sempre frisando a condição de "escritor de primeira viagem".

Se o leitor não considerou satisfatórias as pistas de auto-reflexividade representadas pelos jogos intertextuais, pelas reiteradas exposições sobre as virtualidades da linguagem, pela evocação de autores e características do pósmoderno, ainda há um fio narrativo sobre a busca empreendida por Capitu de uma preciosidade que lhe fora roubada, um pocket-book com o sugestivo título O livro de Borg. Intelectual de seu tempo, o autor faz questão de não deixar dúvidas quanto ao altar em que queima suas oferendas, ele e algo em torno de 90\% dos habitués da ficção ocidental da segunda metade do século XX, quer como leitores, quer como produtores.

O também professor, este de literatura brasileira e teoria literária, Domício Proença Filho, autor de títulos paraditáticos e acadêmicos, com cadeira cativa entre os machadianos, não se limitou à prática do discurso ensaístico e empreendeu aventura de criação. Desde o título - Capitu: memórias póstumas -5 evidencia-se a interseção de outros discursos machadianos. $\mathrm{O}$ relato, quanto ao enredo, segue praticamente pari passu o texto matriz, mas a dona da voz é Capitu. Ela conta com a vantagem de não apenas ter convivido com o marido ressentido, mas também conhecê-lo pelo discurso, além de estar em situação póstuma, como o "irmão Brás" - até melhor por contar com distância temporal maior em relação aos fatos narrados, visto que o tempo da narração é o atual -, e conviver, em espécie de eternidade reservada aos espíritos literários - se assim for possível denominar as personagens ficcionais quando seu tempo de permanência no mundo dos vivos passou -, com outras personagens que, também já libertas do estágio de encarnadas, ajudam-na a analisar o ex-marido e reforçam os ajuizamentos dela. E mais, a Capitu de Proença Filho tem à sua disposição recursos analíticos buscados na psicanálise, tipo de conhecimento que vai lhe permitir definir o marido como "autocentrado", perceber seu caráter ciumento desde sempre e, sobretudo, apresentá-lo como filho fraco da matriarca - termo recorrente no texto - castradora, como a qualificariam Freud e seus discípulos.

5 Rio de Janeiro: Artium, 1998. 
Da posição privilegiada de defunta com acesso ao mundo dos vivos, pode ainda recorrer à fortuna crítica machadiana, enfatizando algumas acusações, incorporando certos termos, reforçando as leituras que, no universo das ações ficcionais, imputam ao modo de ser e ao comportamento de Bento Santiago os motivos do fracasso da união.

Cito um trecho que reúne vários dos traços apontados:

Somos todos na linguagem. Ao assenhorar-se de minha fala ele me atribuiu tal laconismo e contenção, pintou-me de tal forma, que me converteu num mito, num enigma, numa figura sedutora. E mais: tinha por trás dele a arte daquele senhor. (p. 301)

Além da noção de ser de linguagem e da referência àquele senhor, o leitor de estudos machadianos ouve o eco de várias vozes críticas de diversas temporalidades. Em outros momentos, ela saca acusações como a da ausência de paisagem e da desatenção para com a história nacional, transferindo para o narrador Bento, evidentemente porque lhe são desfavoráveis e reforçam o egocentrismo, traços que a crítica apontara em Machado.

A fala dela, que se estende em volumoso relato de mais de três dezenas de páginas, ainda que pelo inverso do laconismo e da contenção, não a torna mais óbvia. Ao se apropriar do discurso para apresentar a sua peça contra o "libelo acusatório", mostra-se advogada de defesa à altura daquele promotor. A réplica tem peso de verdade equivalente à da acusação. Se ele recorreu à insídia para induzir o leitor, ela não é menos arguta na tentativa de reverter o quadro. $\mathrm{O}$ eixo de sua linha de raciocínio chega a ser um golpe baixo: ela se beneficia da sugestividade do texto machadiano e, aproveitando-se das brechas abertas no relato de Bento pela discrição e pela compostura oitocentista, explora a ambigüidade do relacionamento de Bentinho com Escobar desde o tempo do seminário. Se não expõe sem sombra de dúvidas práticas homossexuais do marido, sugere a possibilidade dessas inclinações e declara sem subterfúgios seu baixo desempenho sexual, sua libido mal resolvida, fator desencadeador de seus ciúmes e de seu desequilíbrio.

A seqüência imediata da citação acima antecipa o perigo que corre esse tipo de criação: 
E se a minha fala acabasse contribuindo para a diluição dessa imagem, transformando-me apenas numa mulher ou numa velha senhora ressentida, tão vitimizada quando [sic] o meu algoz? Talvez alguns dos seus leitores até se permitissem negar-me: não, esta não é a imprevisível Capitu... (p. 301)

Apontando a armadilha, ela conta com a possibilidade de reduzi-la à ineficácia. Capitu de Domício sai inteira, ou melhor, é a Capitu de Machado, ou quase. Os recursos a que recorre são resultado da leitura atenta e perspicaz das potencialidades do texto machadiano e da produção crítica. A discreta restrição presente no "quase" acima deriva de uma dose algo excessiva de discurso feminista de diç̧ão de final do século XX, que soa deslocado. Produz efeito anacrônico neste espírito ficcional, se tal denominação é possível, fiel, nos demais aspectos, ao tempo e ao modo da criação da personagem original.

Amor de Capitu ${ }^{6}$ é assinado por escritor com extensa folha de serviços à literatura, autor de muitos títulos de variados gêneros. Fernando Sabino anuncia do que se trata no subtítulo: "O romance de Machado de Assis sem o narrador Dom Casmurro". É de fato um exercício de transposição de discurso de primeira para terceira pessoa, sem alteração efetiva do ponto de vista. O intento, declarado na "Apresentação", é a recriação inspirada "no reconhecimento da importância de um dos monumentos da nossa literatura" (p. 7). Há mais: na leitura de Sabino, ainda conforme a referida "Apresentação", a infidelidade de Capitu é óbvia, mas o intrigante é se a dúvida teria sido premeditada por Machado ou decorreria das "digressões, referências literárias, citações históricas, comentários do pseudoautor travestido em cronista da época” (p. 8). Por isso, o exercício “de eliminar o narrador Dom Casmurro como intermediário entre os fatos por ele vividos e o público-leitor" (p. 9). O que o autor não dá mostras de perceber é que a narração continua filtrada por Bento Santiago, é essa a perspectiva que impera sempre, não se cria outro observador, onisciente ou não.

Há ainda uma espécie de posfácio, do homenageado guardando o título - "E bem, e o resto?" - que reafirma as intenções de homenagem e a impropriedade da crítica que põe em questão a certeza do adultério, além de detalhar as poucas alterações e as razões que as motivaram. Em apêndice são transcritos, ipsis litteris, pelo seu caráter de crônica, os capítulos amputados do enredo.

6 São Paulo: Ática, 1999. 
A produção em espelho não é prerrogativa das letras nacionais. Em cenário mais amplo nem é exatamente uma novidade, embora venha aparecendo com mais freqüência e de modo mais assumido em período recente, quando a noção de originalidade herdada do romantismo deixou de ser exigência primeira. $\mathrm{Na}$ arte contemporânea, a interdiscursividade ocupa posição cada vez mais alargada, especialmente na forma do pastiche e da paródia. Ler esses textos de uma perspectiva comparativista, pressupondo intencionalidade ou objetivo de ocupar o lugar da tradição, desmerece o texto novo e é inócuo para a obra de origem. Até aqui se evitou deliberadamente a recorrência a teorizações, de modo a não deixar os textos de criação submergirem sob o que pode funcionar como um pretexto para generalizações sobre a produção da época. Chega-lhes o risco constante de sufocamento pela magnitude de realização do monumento com que ousaram mexer, ainda que sem jamais desafiá-lo. Entretanto, para inscrevêlos no panorama em que podem aspirar um lugar, é conveniente evocar algumas considerações sobre a contemporaneidade.

Para Linda Hutcheon, as

...formas de arte têm demonstrado cada vez mais que desconfiam da crítica exterior, a ponto de procurarem incorporar o comentário crítico dentro das suas próprias estruturas, numa espécie de autolegitimação que curto-circuita o diálogo crítico normal. ${ }^{7}$

Nas obras abordadas, particularmente nas duas primeiras, parece não ser o caso de considerar que se parta de uma forma de desconfiança para com a crítica, mas antes de uma tentativa de entrar no diálogo que se trava entre criação e crítica, produzindo não o curto-circuito, mas uma ligação alternativa via auto-reflexividade. Estamos diante de trabalhos que são, concomitantemente, criativos e produtivos, apropriando-se de elementos de composições anteriores para recodificá-las, o que é um modo de assimilar o peso do passado. Como quer ainda a já citada crítica canadense que vem se ocupando de teorizar sobre o pós-

7 HUTCHEON, Linda. Uma teoria da paródia. Ensinamentos das formas de arte do século XX. Lisboa: Edições 70, 1989. p. 11. 
modernismo, a assimilação não se faz necessariamente pela semelhança, mas também pela diferença. José Endoença Martins optou pela radicalização do distanciamento, enquanto Domício Proença Filho preferiu construir a diferença na repetição. Fernando Sabino escolheu outra via, confessando intentar contestar a crítica, o que não determina realização de maior alcance.

Talvez se possa considerar Enquanto isso em Dom Casmurro um caso de citação, em que se busca o contraste, a acentuação do distanciamento. Capitu: memórias póstumas apresenta a variedade da paródia reverente, investindo "o outro, simultaneamente, de autoridade e de um valor de troca em relação às normas literárias". ${ }^{8}$ Amor de Capitu constrói-se como pastiche, operando pela semelhança e pela repetição. O primeiro serve-se do original de prestígio para procurar marcar o seu espaço, o segundo constrói seu sentido na operação de síntese bitextual, o último repete sem que se realize a reapropriação. Todos dependem, para se efetivar como leitura, da condição do leitor de transitar do texto primeiro para o atual, reafirmando-se o tributo, pagando-se o preço do prestígio, ainda que sob o risco de ser esmagando pela tradição. O lugar na história literária de obras como estas pode ser o de atestar a permanência de Machado de Assis. É possível afirmar que aquelas que cumprem esse papel têm função assegurada.

\section{RESUMO}

Identificação dos textos ficcionais contemporâneos que dialogam com Dom Casmurro ou com a personagem empírica do autor e caracterização dos processos intertextuais empregados pelos ficcionistas.

Palavras-chave: ficção histórica, ficção contemporânea, metaficção.

\section{ABSTRACT}

An identifying of contemporary fictional texts which dialogue with Dom Casmurro or with the empirical character of the author and a characterization of intertextual process applied by writers.

Key-words: historical fiction, contemporary fiction, metafiction.

8 HUTCHEON, op. cit., p. 99. 


\section{REFERÊNCIAS}

BERNARDO, Gustavo. Lúcia. Rio de Janeiro: Relume-Dumará, 1999.

HUTCHEON, Linda. Uma teoria da paródia. Ensinamentos das formas de arte do século XX. Lisboa: Edições 70, 1989.

MARTINS, José Endoença. Enquanto isso em Dom Casmurro. Florianópolis: Paralelo $27,1993$.

PROENÇA FILHO, Domício. Capitu: memórias póstumas. Rio de Janeiro: Artium, 1998.

SABINO, Fernando. Amor de Capitu. São Paulo: Ática, 1999.

SECCHIN, Antonio Carlos. Carta ao Seixas. In: SECCHIN, Antonio Carlos et al. (Orgs.). Machado de Assis. Uma revisão. Rio de Janeiro: In-Fólio, 1998. p. 131-134.

TREVISAN, Dalton. Capitu sem enigma. Gazeta do Povo, 23 maio 1993. Caderno G, p. 2. . Dinorá. Rio de Janeiro: Record, 1994. 